\title{
Regeneration of Nutrient and Detritus Formation from Aerobic Decomposition of Natural Phytoplankton
}

\author{
Morihiro AIZAKI and Noriko TAKamuRA
}

\begin{abstract}
Respiration and short-term decomposition processes of natural phytoplankton communities collected from eutrophic Lake Kasumigaura were examined eight times in each season from 1983 to 1985 under dark and aerating conditions.

The lag periods were observed for the increase of nutrient and the decrease of cell components during the initial period of the incubation. This fact suggested that most of the phytoplankters were living in the initial few days under these conditions. Since the nutrient regeneration seemed to be unrelated to the oxygen consumption rate, it was considered that the change in nutrient concentration had to be measured directly for estimation of the regeneration rate, and this measurement was useful to distinguish between decomposition and respiration processes of phytoplankton.

The decomposition process could be described as a first order process in the initial period. The relative rates of decrease of the measured parameters were as follows; chlorophyll $>$ nitrogen $>$ carbon. Decomposition and nutrient regeneration rates seemed to be affected by water temperature and the algal species composition. Bluegreen algae easily decomposed at high temperature, but diatoms did not.

About $70-90 \%$ of cell carbon and nitrogen were easily mineralized to $\mathrm{CO}_{2}$ and dissolved inorganic nitrogen, and only about $10-30 \%$ changed to detritus carbon and nitrogen. About $24 \%$ of cell phosphorus was regenerated in average and the remainder was in the particulate form.
\end{abstract}

Key words: nutrient regeneration, detritus formation, plankton decomposition, respiration

\section{Introduction}

Respiration and decomposition processes of phytoplankton are important for mineralization of carbon and nutrient cycling in the aquatic ecosystem. These two processes are essentially different, because the former process takes place in living cells and the latter in dead plankton. However, it is difficult to distinguish between the two processes under natural conditions because of the few available in-situ methods for determination of the decomposition rate. The oxygen consumption rate has been often used to determine both respiration and decomposition rates ( $F_{\text {ALLON }}$ and BROCK,
1979). Until quite recently, regeneration of soluble phosphorus and nitrogen from the decomposition of phytoplankton was estimated by many investigators on the assumption that nutrient regeneration was coupled with oxygen consumption. The Redfield ratio (REDFEID et al., 1963) has been widely used. However, several investigators reported that phosphorus and nitrogen regenerations depend on the initial cellular $\mathrm{C}, \mathrm{N}$ and $\mathrm{P}$ compositions and are not coupled with oxygen consumption (DEPINTO and Verhoff, 1977; Stockli, 1985; Gächter and Mares, 1985; TezuKa, 1986, 1989a, 1989b). Thus, the relationships among respiration, decomposition and nutrient regeneration proces- 
ses are somewhat confused. The present study was carried out to clarify these relationships.

The process of phytoplankton decomposition is also important for detritus formation. Algal detritus produced by the decomposition of phytoplankton is the most important detritus for food webs, because of its lower fiber content and higher nitrogen content (MANN, 1988). However, studies on detritus formation by phytoplankton decomposition are few (Golterman, 1972).

In the present study, respiration and shortterm decomposition processes of natural phytoplankton communities collected from eutrophic Lake Kasumigaura were examined under dark and aerating conditions. Changes in concentrations of several components of algal cells were determined for the estimations of decomposition rate and detritus formation rate, and nutrient regeneration rate was also studied.

\section{Materials and methods}

Surface waters of Takahamairi Bay, Lake Kasumigaura, were used for this experiment. After filtration with NXX 13 plankton net for removal of zooplankton, water samples were poured into a 100-liter plastic tank and maintained under dark and aerating conditions in a temperature controlled room. Aeration was carried out using an airpump with an airstone. Temperature was kept at about the same temperature in the field. Eight different runs were conducted in each season from 1983 to 1985 . Experimental conditions are shown in Table 1. About one liter of water sample was withdrawn from the tank after complete mixing at $0.5-4$ days interval. After a portion was taken for analyses of photosynthesis and respiration rates, determination of species composition, enumeration of heterotrophic bacterial number and total phosphorus analysis, the remainder was passed through a Whatman GF/ $\mathrm{C}$ or a Millipore AP40 glass fiber filter which was preignited at $450^{\circ} \mathrm{C}$ for $3 \mathrm{hr}$. Both the filters holding particulate matter and filtrates were used for chemical analyses.

Photosynthetic and respiration rates and species composition were determined using the methods described in the previous paper (TAKamura et al., 1987). Total heterotrophic bacterial number was estimated using the MPN method on a one-tenth concentration of nutrient broth (Difco) after incubation at $20^{\circ} \mathrm{C}$ for two weeks in the dark.

Chemical analyses were performed by the following methods; chlorophyll- $a$ (chl- $a$ ) by the method of UNESCO/SCOR (STRICKLAND and Parsons, 1972) after the extraction of the pigment with 90\% acetone; particulate organic carbon (POC) and nitrogen (PON) with a $\mathrm{CHN}$ corder (Yanaco MT-3); dissolved organic carbon (DOC) by the method of MENZEL and VAccaro (1964); total phosphorus (TP), dissolved total phosphorus (DTP) and nitrogen (DTN) with an autoanalyzer (Technicon AA2) after persulfate digestion; reactive phosphorus $\left(\mathrm{PO}_{4}-\mathrm{P}\right)$, ammonium nitrogen $\left(\mathrm{NH}_{4}-\mathrm{N}\right)$, nitrite nitrogen $\left(\mathrm{NO}_{2}-\mathrm{N}\right)$ and nitrate nitrogen $\left(\mathrm{NO}_{3}{ }^{-}\right.$ $\mathrm{N})$ also using an autoanalyzer (Technicon AA2) (Otsuki and Sekiguchi, 1983; Otsuki et al., 1987). Total inorganic nitrogen (TIN) concentration was determined by summing the concentrations of $\mathrm{NH}_{4}-\mathrm{N}, \mathrm{NO}_{2}-\mathrm{N}$ and $\mathrm{NO}_{3}-\mathrm{N}$.

\section{Results}

\section{3-1. Distinction between respiration and decomposition processes}

The dominant species were shown in Table 1 for each experiment. From July to October, Microcystis spp. predominated except in July 1983. Anabaena flos-aquae predominated in July 1983, Crysophyceae in February 1984 and Synedra sp. in May 1984.

Time courses of several parameters during the incubation of phytoplankton under dark and aerating conditions are shown in Figure 1. The concentrations of chl- $a$ and PON decreased after a lag period of about 4 days. $\mathrm{PO}_{4}-\mathrm{P}$ and DTN concentrations increased after almost the same lag period. On the contrary, the POC concentration decreased slowly without any lag period during initial about 4 days, subsequently that decreased rapidly. In the time course of inorganic nitrogen, $\mathrm{NH}_{4}-\mathrm{N}$ concentration initially increased but then decreased; $\mathrm{NO}_{2}-\mathrm{N}$ concentration increased, but 
Table 1. Experimental temperature and dominant species of phytoplankton in each experimental run.

\begin{tabular}{|c|c|c|c|}
\hline \multicolumn{2}{|c|}{ Exp. Time } & \multirow{2}{*}{$\frac{\text { Dominant species }}{\text { Anabaena flos-aquae }}$} & \multirow{2}{*}{$\frac{\mathrm{W} . \mathrm{T} .\left({ }^{\circ} \mathrm{C}\right)}{25}$} \\
\hline Jul. & 1983 & & \\
\hline Aug. & 1983 & Microcystis & 25 \\
\hline Sep. & 1983 & Microcystis & 30 \\
\hline Oct. & 1983 & Microcystis (Melosira) & 20 \\
\hline Feb. & 1984 & Crysophyceae (Cyclotella) & 5 \\
\hline May & 1984 & Synedra (Aphanizomenon) & 13 \\
\hline Jul. & 1984 & Microcystis & 25 \\
\hline Jul. & 1985 & Microcystis & 25 \\
\hline
\end{tabular}

Secondarily dominant species.
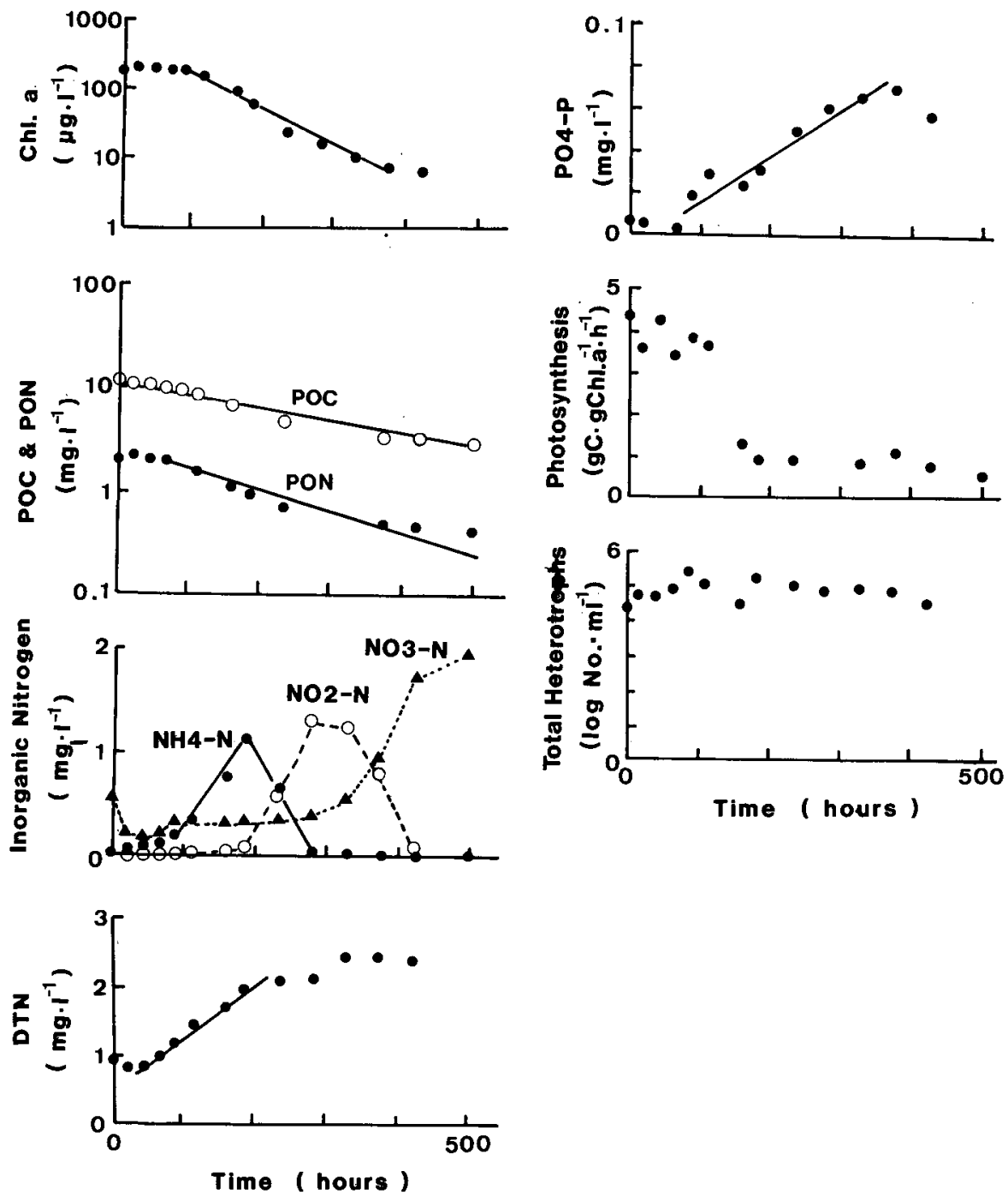

Fig. 1. Time courses of several parameters during the incubation of phytoplankton under dark and aerating conditions in July 1984. 
eventually decreased, and $\mathrm{NO}_{3}-\mathrm{N}$ concentration increased. These changes showed that ammonification of organic nitrogen occurred at first, followed by nitrification. Photosynthetic activity maintained relatively high values during the initial 4 days, but then decreased rapidly. The number of total aerobic heterotrophs increased about 10 times during the initial 2-3 days, and then maintained almost the same number. The patterns of these time courses of each parameter for the other experimental runs were similar (see Fig. 1).

Initial lag periods of each parameter were almost the same in each experimental run (Table 2), and the concentrations and activities changed rapidly after the lag period. This fact suggests that most of the phytoplankter incubated under dark and aerating conditions were living for the initial several days, but that some thereafter died and decayed.

Figures 2 and 3 show the time courses of photosynthetic activity and respiration rate in each experimental run, respectively. The photosynthetic activities varied from 2 to $5 \mathrm{gC}$. gchl $-a^{-1} \cdot \mathrm{hr}^{-1}$ during the initial $15-150$ hours except in September 1983. Then the activities decreased rapidly and showed less than $2 \mathrm{gC}$ gchl- $a^{-1} \cdot \mathrm{hr}^{-1}$. The initial respiration rate ranged from 6.1 to $162 \mathrm{mgO}_{2} \cdot \mathrm{m}^{-3} \cdot \mathrm{hr}^{-1}$ except in September 1984. Higher rates were observed in summer periods. In September 1984, this rate was extremely high as $696 \mathrm{mgO}_{2} \cdot \mathrm{m}^{-3} \cdot \mathrm{hr}^{-1}$ due to the high density of phytoplankton. This rate decreased in the initial incubation period but was rather constant in the following period except in July 1984, when the rate increased at $70 \mathrm{hr}$ after the incubation and reached the maximum of $220 \mathrm{mgO}_{2} \cdot \mathrm{m}^{-3} \cdot \mathrm{hr}^{-1}$ at $150 \mathrm{hr}$, then decreased. This increase in the middle period of the incubation seemed be caused by the high activity of heterotrophic decomposition of phytoplankton, but the reason why the high heterotrophic activity was observed only this time was obscure.

\section{3-2. Decomposition rate of phytoplankton}

Figure 4 shows the changes in concentrations of chl- $a$ in each experiment. These levels decreased after the lag period, which ranged from 40 to $115 \mathrm{hr}$. Initial concentrations of chl- $a$ ranged widely. The highest concentration of $594 \mu \mathrm{g} \cdot 1^{-1}$ was observed in September 1983 , and the lowest value of $8.1 \mu \mathrm{g} \cdot 1^{-1}$ was noted in February 1984. In May 1984, the chl- $a$ concentration decreased slowly and remained

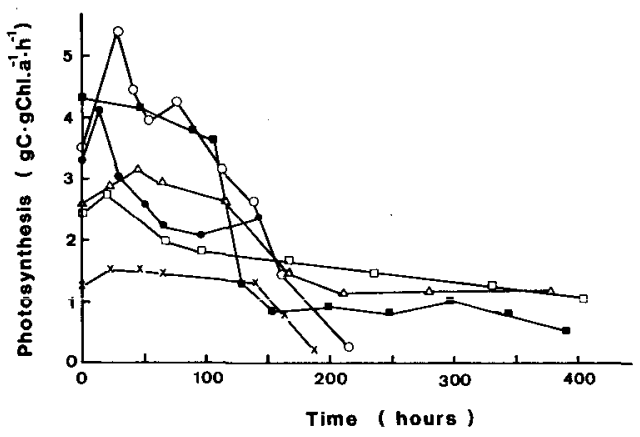

Fig. 2. Changes in photosynthetic activities during the incubation of phytoplankton under dark and aerating conditions in each experimental run. (O), Jul. 1983; (O), Aug. 1983; (×), Sep. 1983; $\triangle$ ( ), Oct. 1983;

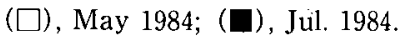

Table 2. Lag times (hr) of increase of TIN and $\mathrm{PO}_{4}-\mathrm{P}$ concentrations, and decrease of POC, PON and chl- $a$ concentrations and photosynthetic activity in each experimental run under dark and aerating incubation.

\begin{tabular}{llrrrrrr}
\hline \multicolumn{2}{r}{ Exp. time } & TIN & PO $_{4}-\mathrm{P}$ & POC & PON & Chl- $a$ & Photosynthesis \\
\hline Jul. & 1983 & 15 & 35 & 10 & 40 & 70 & 15 \\
Aug. 1983 & 65 & 75 & 25 & 140 & 115 & 75 \\
Sep. $\quad 1983$ & 70 & 120 & 120 & 120 & 100 & 140 \\
Oct. 1983 & 65 & 0 & 45 & 115 & 115 & 115 \\
Feb. $\quad 1984$ & 20 & - & 140 & 140 & 70 & - \\
May & 1984 & 70 & 70 & 120 & 95 & 95 & 20 \\
Jul. & 1984 & 45 & 70 & 70 & 90 & 90 & 105 \\
Jul. & 1985 & 20 & 20 & 20 & 40 & 40 & - \\
\hline
\end{tabular}




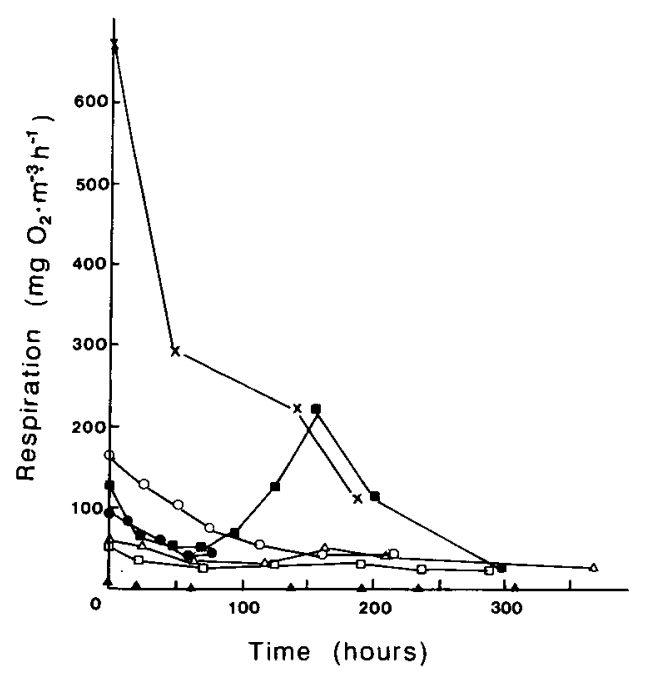

Fig. 3. Changes in respiration rates during the incubation of phytoplankton under dark and aerating conditions in each experimental run. (O), Jul. 1983; (O), Aug. 1983; $(\times)$, Sep. 1983; $(\triangle)$, Oct. 1983; $(\square)$, May 1984; (ロ), Jul. 1984.

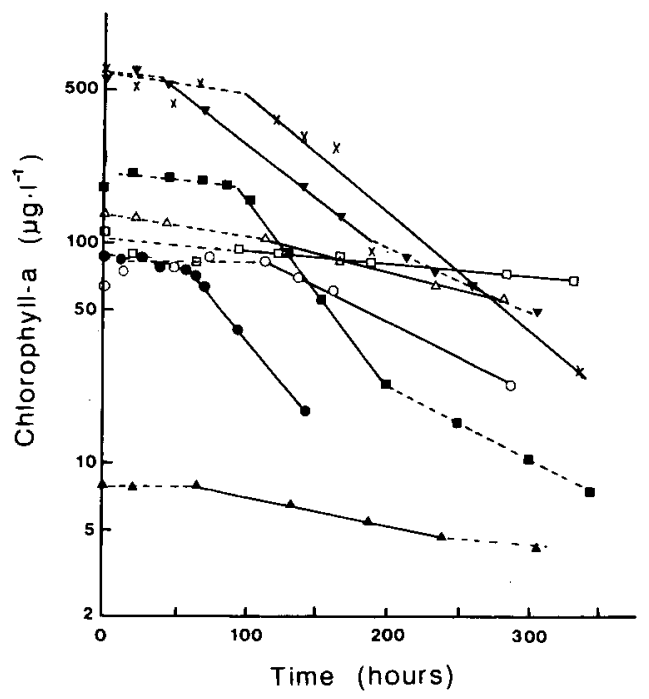

Fig. 4. Changes in the concentration of chlorophyll-a during the incubation of phytoplankton under dark and aerating conditions in each experimental run. (O), Ju1. 1983; (O), Aug. 1983; ( $\times$ ), Sep. 1983; ( $\triangle$ ), Oct. 1983; (A), Feb. 1984; ( $\square$ ), May 1984; (ם), Jul. 1984; ( $\mathbf{\nabla})$, Jul. 1985. at about half of the initial level at 20 days after the start of incubation.

Many investigators (e.g., OTsuki and Hanya, 1972) reported that the decomposition process of phytoplankton could be described by a first order kinetic model $\left(C_{b}=C_{a} * 10^{-k t} ; C_{b}\right.$, concentration after $t$ hr from the start of incubation; $C_{a}$, concentration at the start time; $k$, decomposition rate constant). In this study, the decomposition process was also followed by the first order kinetic model during the initial stage of decomposition process. Decomposition rate constants of chl- $a\left(K_{\mathrm{chl}}\right)$ were estimated from the region marked by solid lines in Figure 4. The highest value of $0.205 \cdot \mathrm{d}^{-1}$ was observed in July 1984, and the lowest value of $0.016 \cdot \mathrm{d}^{-1}$ was seen in May 1984 (Table 3 ). In summer, the decomposition rate constants showed relatively high values.

Figure 5 shows the changes in POC concentrations during the incubation period in each experiment. The concentration decreased slowly in the initial 10-140 hr, and then fell rapidly. The initial phase seemed to be consumption by phytoplankton respiration, while the latter phase was caused through the phytoplankton decomposition by associated microorganisms. DOC concentrations scarcely changed with the ongoing phytoplankton decomposition except in February 1984. This suggests that dissolved organic materials released by decomposition of phytoplankton were easily utilized by associated bacteria and mineralized to $\mathrm{CO}_{2}$. Decomposition rate constants of carbon $\left(K_{c}\right)$ were estimated in the latter phase (Table 3). Relatively high values of $0.066^{-}$ $0.098 \cdot \mathrm{d}^{-1}$ were observed in July and September, whereas, in August the value was relatively low at $0.047 \cdot \mathrm{d}^{-1}$, with the lowest level in May.

Figure 6 shows the changes of PON concentration for each experiment. The pattern of the time course at each experimental time was almost the same as that of $\mathrm{chl}^{-} a$ and POC. The initial lag period ranged from 40 to $140 \mathrm{hr}$. The shortest lag periods were observed in July 1983 and 1985, and the longest one in May 1984. Decomposition rate constants of PON $\left(K_{N}\right)$ ranged $0.015-0.139 \cdot \mathrm{d}^{-1}$ (Table 3 ). In summer 
Table 3. Decomposition rate constants of several phytoplankton components under dark and aerating incubation.

\begin{tabular}{llccc}
\hline Exp. Time & $\begin{array}{c}\text { Chl-a } \\
\mathrm{K}_{\mathrm{ch} 1}\left(\mathrm{~d}^{-1}\right)\end{array}$ & $\begin{array}{c}\text { POC } \\
\mathrm{K}_{\mathrm{c}}\left(\mathrm{d}^{-1}\right)\end{array}$ & $\begin{array}{c}\text { PON } \\
\mathrm{K}_{\mathrm{N}}\left(\mathrm{d}^{-1}\right)\end{array}$ \\
\hline Jul. 1983 & 0.130 & 0.098 & 0.139 \\
Aug. 1983 & 0.077 & 0.047 & 0.082 \\
Sep. 1983 & 0.120 & 0.068 & 0.101 \\
Oct. 1983 & 0.040 & 0.027 & 0.033 \\
Feb. 1984 & 0.023 & 0.036 & 0.029 \\
May & 1984 & 0.016 & 0.005 & 0.015 \\
Jul. 1984 & 0.205 & 0.056 & 0.096 \\
Jul. & 1985 & 0.111 & 0.066 & 0.074 \\
\hline
\end{tabular}

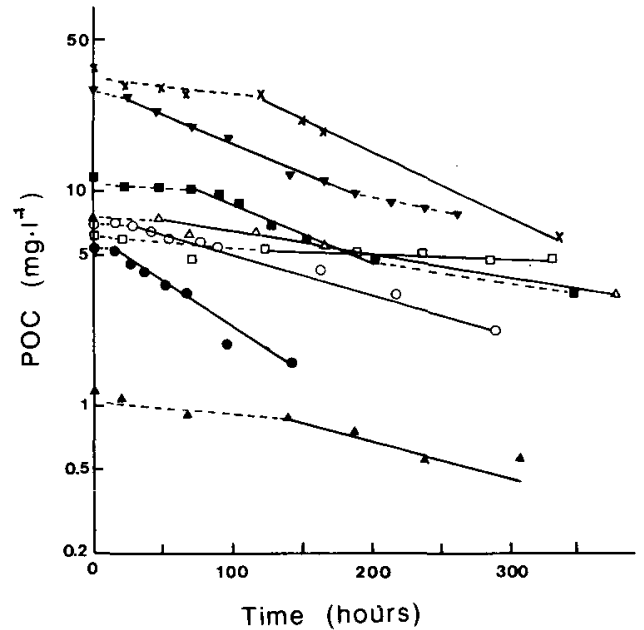

Fig. 5. Changes in the concentration of POC during the incubation of phytoplankton under dark and aerating conditions in each experimental run. ( $)$, Jul. 1983; $(\bigcirc)$,

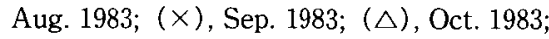

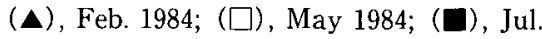
1984; ( $)$, Jul. 1985.

the values were relatively high at $0.074-0.139$ $\mathrm{d}^{-1}$, and the lowest level was $0.015 \cdot \mathrm{d}^{-1}$ in May 1984.

\section{3-3. Regeneration of Nutrient}

Figure 7 shows the changes in TIN concentrations during the incubation period for each experiment. In the initial $15-70 \mathrm{hr}$, the concentration was rather constant except in July and August 1983 and July 1984. At these three times the concentrations decreased in the initial $20-50 \mathrm{hr}$. After the initial lag periods the con-

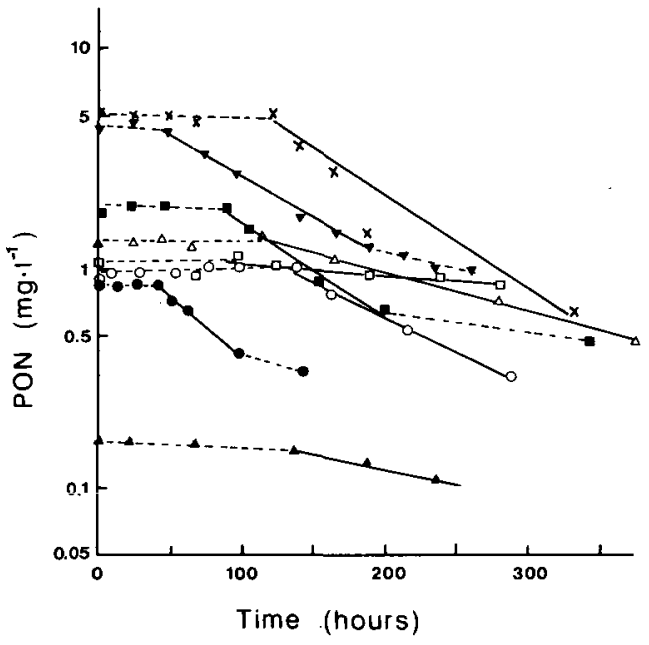

Fig. 6. Changes in the concentration of PON during the incubation of phytoplankton under dark and aerating conditions in each experimental run. (๑), Júl. 1983; $(\bigcirc)$, Aug. 1983; $(\times)$, Sep. 1983; $(\triangle)$, Oct. 1983; (ム), Feb. 1984; ( $\square$ ), May 1984; (四), Jul. 1984; ( $\mathbf{\nabla})$, Jul. 1985.

centrations rose rapidly except in Februray 1984. The average regeneration rate of nitrogen for each experimental run was calculated from the increasing amount of TIN and the time of the logarithmic phase and shown in Table 4. In September 1983 the highest rate of $1.033 \mathrm{mg} \cdot \mathrm{l}^{-1} \cdot \mathrm{d}^{-1}$ was observed, and the rate ranged from 0.107 to $0.455 \mathrm{mg} \cdot 1^{-1} \cdot \mathrm{d}^{-1}$ during summer period. The lowest rate of $0.007 \mathrm{mg}$. $\mathrm{I}^{-1} \cdot \mathrm{d}^{-1}$ was observed in February 1984.

Figure 8 shows the relationship between the 


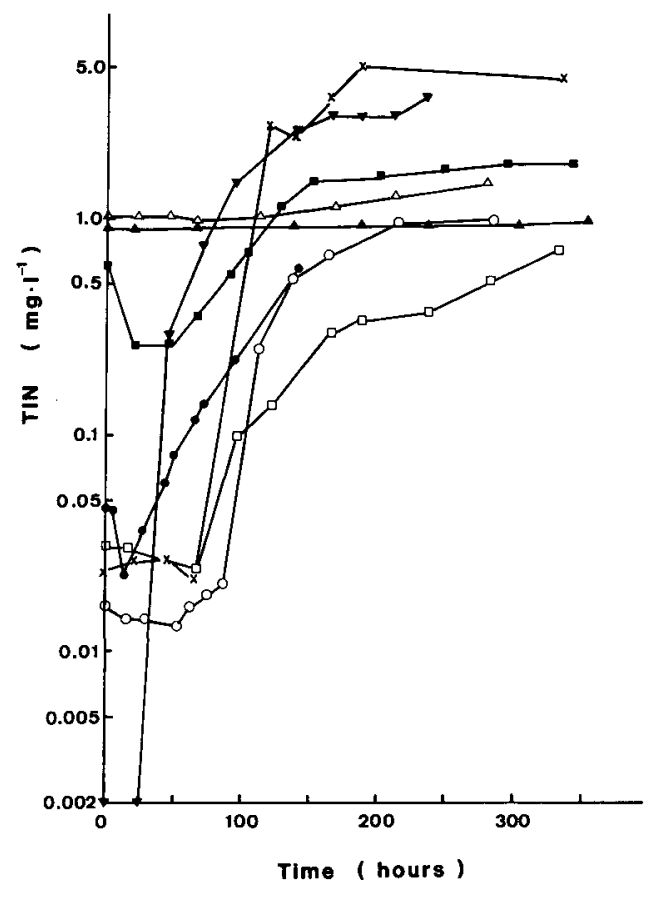

Fig. 7. Changes in the concentration of TIN during the incubation of phytoplankton under dark and aerating conditions in each experimental run. (๑), Jul. 1983; (O), Aug. 1983; (×), Sep. 1983; ( $\triangle)$, Oct. 1983;

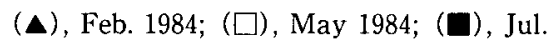
1984; ( $\mathbf{\nabla})$, Jul. 1985.

Table 4. Average regeneration rates $\left(\mathrm{mg} \cdot \mathrm{l}^{-1}\right.$. $\mathrm{d}^{-1}$ ) of phosphorus and nitrogen during the initial decomposing period of phytoplankton under the dark and aerating incubations.

\begin{tabular}{|c|c|c|c|}
\hline \multicolumn{2}{|c|}{ Exp. Time } & \multirow{2}{*}{$\frac{\mathrm{PO}_{4}-\mathrm{P}}{0.056}$} & \multirow{2}{*}{$\frac{\text { TIN }}{0.107}$} \\
\hline Jul. & 1983 & & \\
\hline Aug. & 1983 & 0.008 & 0.145 \\
\hline Sep. & 1983 & 0.072 & 1.033 \\
\hline Oct. & 1983 & 0.104 & 0.066 \\
\hline Feb. & 1984 & - & 0.007 \\
\hline May. & 1984 & 0.003 & 0.064 \\
\hline Jul. & 1984 & 0.006 & 0.286 \\
\hline Jul. & 1985 & 0.039 & 0.455 \\
\hline
\end{tabular}

total amounts of PON decrease and TIN increase during each experimental period. A significant correlation was observed. In September 1983, the largest values of PON decrease $\left(4.39 \mathrm{mg} \cdot 1^{-1}\right)$ and TIN increase (4.51 $\left.\mathrm{mg} \cdot \mathrm{l}^{-1}\right)$ were observed. The difference between the decrease and increase seemed to be an analytical error. The lowest levels ( $c a .0 .1$ $\mathrm{mg} \cdot \mathrm{1}^{-1}$ ) were observed in February 1984. Regenerated TIN amounts were about 70-90\% of initial PON concentrations except in October 1983.

Figure 9 shows the changes in $\mathrm{PO}_{4}-\mathrm{P}$ concentrations during the incubation period at each experimental run. During the initial 20-120 hr the concentrations decreased except in October 1983 and February 1984. Subsequently, the levels rose rapidly. In October 1983 the concentration inexplicably increased soon after the incubation, and seemed to be unrelated to with the decomposition of phytoplankton. In February 1984 the concentration was under the detectable value throughout the experimental period. The average regeneration rate of phosphorus for each experimental time was calculated from the increasing amount of $\mathrm{PO}_{4}$ -

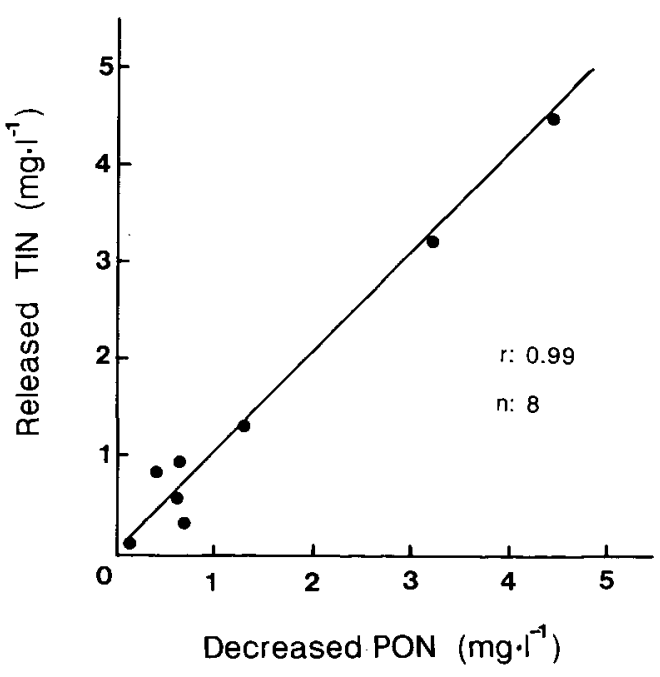

Fig. 8. Relationship between the total amounts of decreased PON and released TIN during the incubation of phytoplankton under dark and aerating conditions. $(Y=1.02 X+$ $0.05)$. 


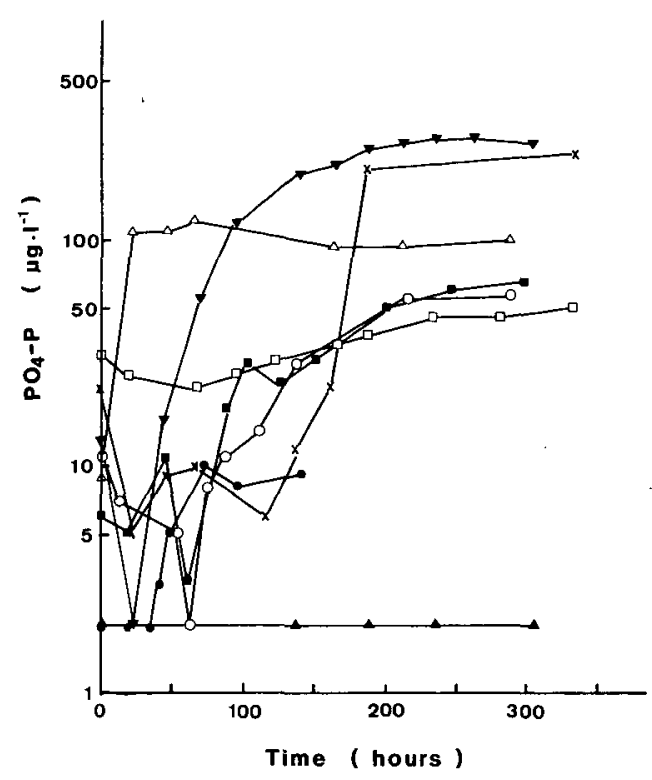

Fig. 9. Changes in the concentration of $\mathrm{PO}_{4}-\mathrm{P}$ during the incubation of phytoplankton under dark and aerating conditions in each experimental run. (๑), Jul. 1983; (O),

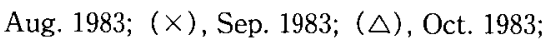
(А), Feb. 1984; ( $\square$ ), May 1984; (ロ), Jul. 1984; ( $\boldsymbol{\nabla})$, Jul. 1985.

$\mathrm{P}$ and the time of the logarithmic phase and shown in Table 4. The highest value of 0.104 $\mathrm{mgP} \cdot \mathrm{l}^{-1} \cdot \mathrm{d}^{-1}$ was observed in October 1983. The rate ranged from 0.006 to $0.072 \mathrm{mg} \cdot 1^{-1} \cdot \mathrm{d}^{-1}$ during summer period and fell to nearly zero in winter period.

Figure 10 shows the linear correlation between the total amounts of regenerated TIN and $\mathrm{PO}_{4}{ }^{-}$ $\mathrm{P}$ during experimental period. The average released $\mathrm{TIN} / \mathrm{PO}_{4}-\mathrm{P}$ ratio was estimated as 14.4. Figure 11 shows the relationship between $\mathrm{N} / \mathrm{P}$ ratio of phytoplankton before the incubation and the released TIN $/ \mathrm{PO}_{4}-\mathrm{P}$ ratio except in October 1983, February 1984 and July 1985. As mentioned above, in October 1983 it was considered that the $\mathrm{PO}_{4}-\mathrm{P}$ increase did not depend on phytoplankton decomposition, in February $1984 \mathrm{PO}_{4}-\mathrm{P}$ increase could not be detected, and in July 1985 the total phosphorus concentration was not determined. It is evident from the figure that released TIN $/ \mathrm{PO}_{4}-\mathrm{P}$ ratio increased sharply with the increase of $\mathrm{N} /$

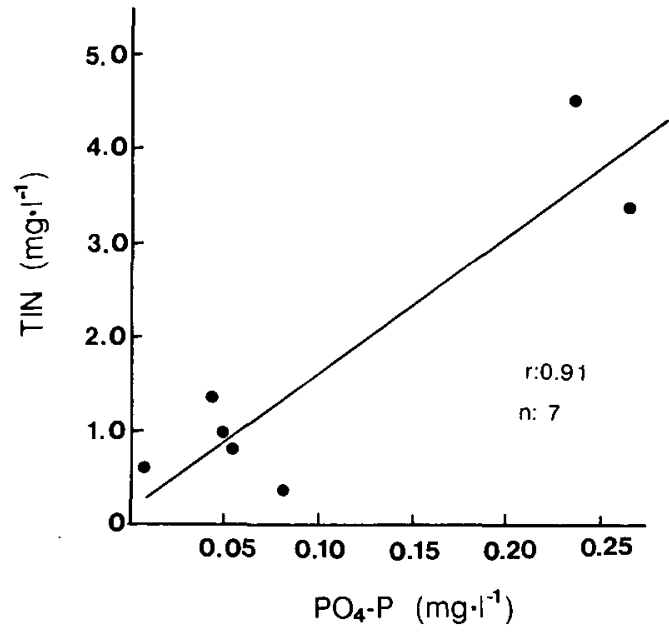

Fig. 10. Relationship between the total amounts of released $\mathrm{PO}_{4}-\mathrm{P}$ and TIN during the incubation of phytoplankton under dark and aerating conditions. ( $Y=14.4 X+$ 0.20 ).

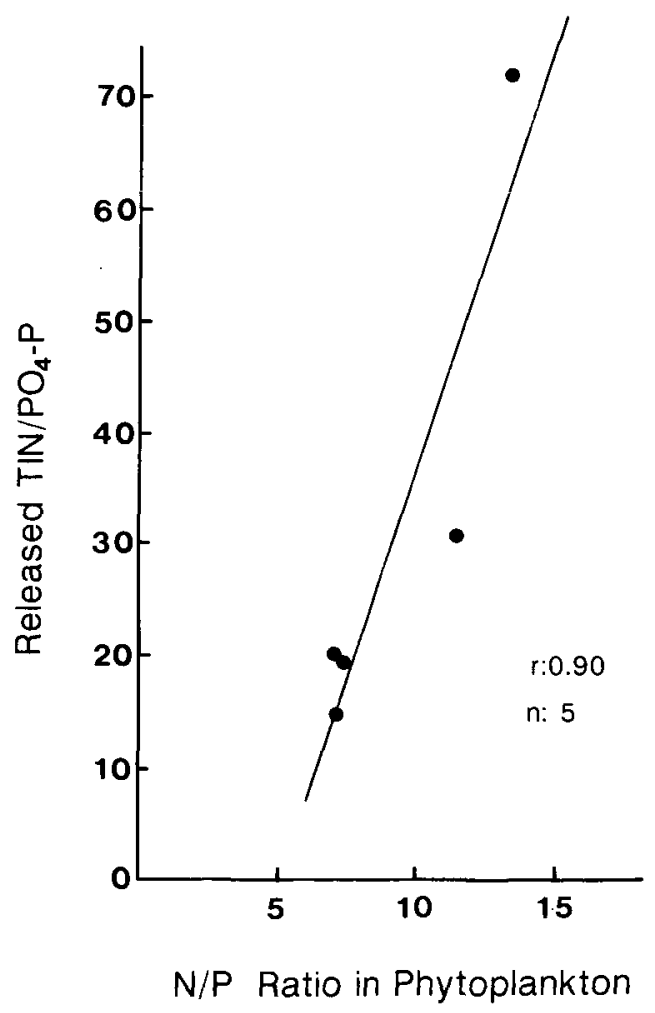

Fig. 11. Relationship between the $N / P$ ratios of phytoplankton before the incubation and released $\mathrm{TIN} / \mathrm{PO}_{4}-\mathrm{P}$ ratios. 
$P$ ratio of initial phytoplankton.

\section{3-4. Detritus formation from decompos- ing phytoplankton}

Figure 12 shows the changes in $\mathrm{C} / \mathrm{chl}-a$ ratio during the incubation periods. The ratio remained almost constant during the initial few days and increased thereafter except in August 1983 and February 1984. The lag times before rapid increase of the values ranged from $70 \mathrm{hr}$ in July 1983 to $280 \mathrm{hr}$ in May 1984. The initial ratios ranged from 50 to 65 except in August and February 1984, when the initial $\mathrm{C} / \mathrm{chl}-a$ ratios were very high. The values decreased soon after the start of incubation.

In this study, it was considered that the increase of $\mathrm{C} / \mathrm{chl}-a$ ratio in the latter period was due to the formation of detritus carbon. Thus, if the $\mathrm{C} / \mathrm{chl}-a$ ratio of living cells is constant in each experimental run, the amount of detritus carbon produced by decomposition of phytoplankton can be calculated by the following formula;

$$
A=P O C_{t}-C h l_{t} \times C / C h l_{i}
$$

where, $A$ is detritus carbon amount, $P O C_{t}$ and $C h l_{t}$ are POC and chl- $a$ concentrations at $t \mathrm{hr}$ after the start of incubation, respectively, and $\mathrm{C} / \mathrm{Chl}_{i}$ is the mean $\mathrm{C} / \mathrm{chl}$ ratio during the initial lag period.

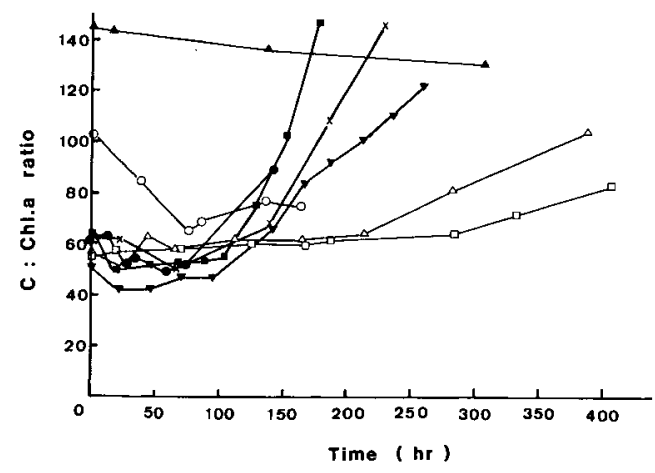

Fig. 12. Changes in the $\mathrm{C} / \mathrm{chl}-a$ ratio during the incubation of phytoplankton under dark and aerating conditions in each experimental run. (๑), Jul. 1983; (O), Aug.

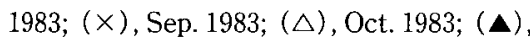

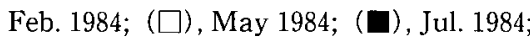
( $)$, Jul. 1985.
Figure 13 shows the detritus carbon formation. In summer when Microcystis sp. predominated, the rates of detritus carbon formation were very high. The amount of detritus reached $3.4-4.6 \mathrm{mg} \cdot \mathrm{l}^{-1}$ and hardly changed thereafter except in July 1983. In October and May the formation rates were relatively low, and the amount of produced detritus carbon was about $1.2 \mathrm{mg} \cdot \mathrm{l}^{-1}$. The ratios of detritus carbon amount to initial POC amount ranged from 12 to $30 \%$. The highest value was observed in July 1984 and the lowest in September 1983. In August 1983 and February 1984, no detritus formation was observed during the experimental period.

Detritus nitrogen formation was also estimated by almost the same method as for detritus carbon. The result is shown in Figure 14. The amount of detritus nitrogen ranged from 0.22 to $0.55 \mathrm{mg} \cdot 1^{-1}$, and relatively high values were observed in summer periods. In August 1983 and May 1984 the amounts were relatively low. The ratios of detritus nitrogen amount to initial PON amount ranged from 11 to $24 \%$. The highest value was observed in July 1984. C/ $\mathrm{N}$ ratios of the produced detritus ranged from 7.2 to 8.0 except in July 1985 . In July 1985 , the $\mathrm{C} / \mathrm{N}$ ratio was relatively high at

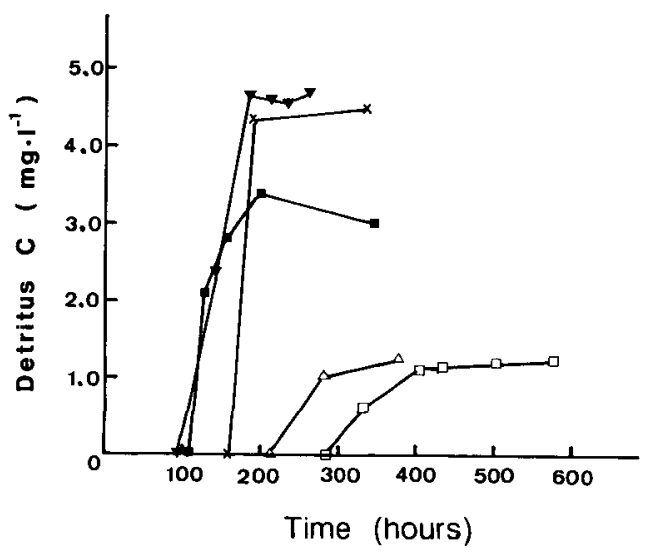

Fig. 13. Detritus carbon formation during the incubation of phytoplankton under dark and aerating conditions in each experimental run. $(\times)$, Sep. 1983; $(\triangle)$, Oct, 1983; ( $\square$ ), May 1984; ( $)$, Jul. 1984; ( $\boldsymbol{\nabla})$, Jul. 1985 . 


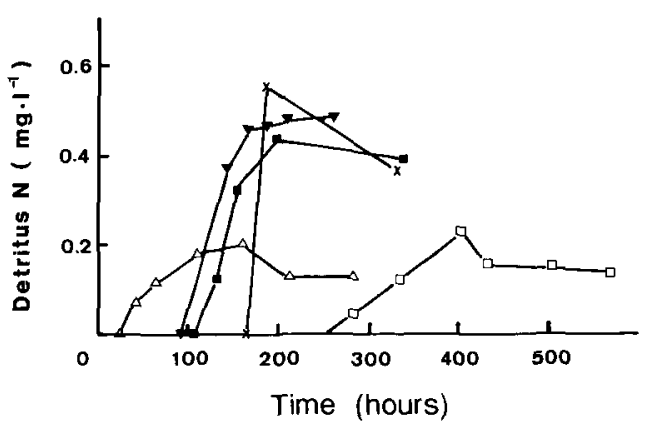

Fig. 14. Detritus nitrogen formation during the incubation of phytoplankton under dark and aerating conditions in each experimental run. $(\times)$, Sep. 1983; $(\triangle)$, Oct.

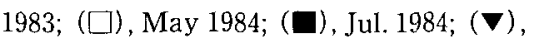
Jul. 1985.

9.6. These $\mathrm{C} / \mathrm{N}$ ratios were slightly higher than the values of natural phytoplankton communities before the incubations.

\section{Discussion}

Many investigators have studied the decomposition process of phytoplankton. However, the relationship among the respiration, decomposition and nutrient regeneration processes was not clarified. As shown in Table 2, the lag periods were observed for the increase of nutrient and the decrease of cell components during the incubation of natural phytoplankton under aerobic and dark conditions. This fact suggested that most of the phytoplankter were living in the initial few days under these conditions. Since the nutrient regeneration was not observed in this period, the oxygen consumption seemed to be mainly due to the respiration of living phytoplankton. Watanabe and KimURA (1990) reported that respiration activity was related to the amount of carbohydrate accumulated in the algal cells during light period by photosynthesis. The initial decrease of the respiration rate observed in each experimental run seemed to be due to the consumption of the accumulated carbohydrate in the cells (Fig. 3).

Since the oxygen consumption rates were rather constant except for July 1984 in the latter period of the incubation, it was difficult to separate the heterotrophic oxygen consumption from the respiration of living phytoplankton. The nutrient regeneration could not be readily estimated from the oxygen consumption rate. Therefore, the change in nutrient concentration had to be measured directly to estimate the regeneration rate, and this measurement was useful to distinguish between decomposition and respiration processes of phytoplankton.

Many investigators studied the nutrient regeneration rate on the basis of the phytoplankton decomposition. Tezuka (1989a, b) reported that $\mathrm{C}: \mathrm{N}$ : $\mathrm{P}$ ratio of phytoplankton was important for nutrient regeneration. In this experiment, $\mathrm{C} / \mathrm{N}$ ratios of the phytoplankton communities before incubation ranged from 5.9 to 8.3 with a mean value of 6.7 . These levels reflected the moderate nitrogen condition for the growth of phytoplankton (HEALEY and Hendzel, 1979, 1980). Therefore, the amount of released nitrogen may correspond to the amount of decreased PON (Fig. 8).

As shown in Figure 10, the amount of released phosphorus was closely related to that of nitrogen, and released TIN/ $\mathrm{PO}_{4}-\mathrm{P}$ ratio was estimated as 14 . However, this ratio was also related to the $\mathrm{N} / \mathrm{P}$ ratio of phytoplankton before the incubation (Fig. 11). According to Healay and Hendzel $(1979,1980), \mathrm{N} / \mathrm{P}$ ratio from 10 to 20 indicated a moderate $\mathrm{P}$ deficient condition. In this condition, released TIN/ $\mathrm{PO}_{4}-\mathrm{P}$ ratios showed high values of 31 and 73 . This fact indicated that regeneration of phosphorus was inhibited under moderate and severe $\mathrm{P}$ deficient conditions in comparison with nitrogen regeneration. Further investigation is needed for this relationship, because of both insufficient data and range of $\mathrm{N} / \mathrm{P}$ ratio of phytoplankton.

As shown in Table 3, decomposition rate constants showed a large seasonal variation. Figure 15 shows the relationship between water temperature and the decomposition rate constant of POC $\left(\mathrm{K}_{\mathrm{c}}\right)$. The correlation was not significant. It was considered from the figure that decomposition rate was affected by phytoplankton species. Anabaena flos-aquae and 


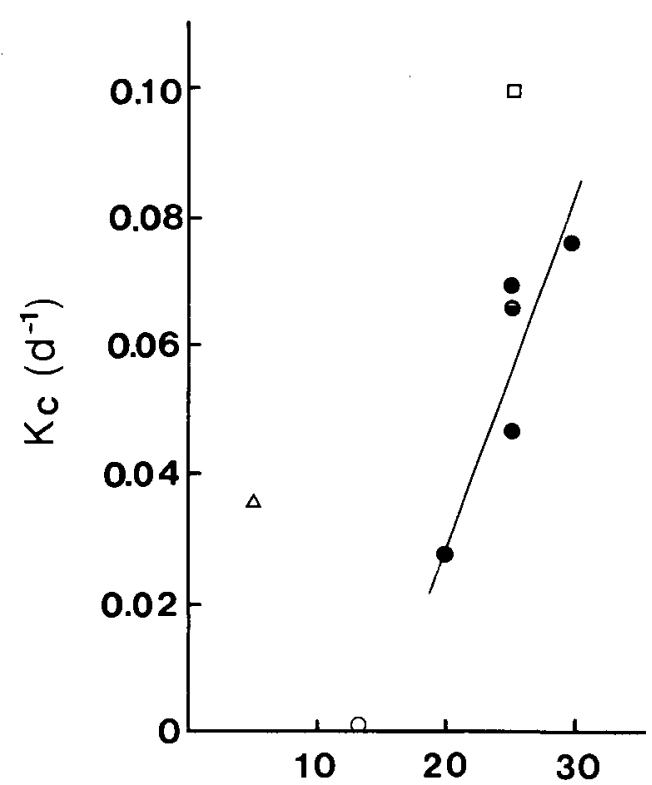

Water Temp. $\left({ }^{\circ} \mathrm{C}\right)$

Fig. 15. Relationship between water temperature and the decomposition rate constants of POC during the incubation of phytoplan. kton under dark and aerating conditions. Dominant species: (О), Microcystis sp.; ( $\square)$, Anabaena flos-aquae; (O), Synedra sp.; $(\triangle)$, Crysophyceae.

Crysophyceae easily decomposed, but diatom did not. These results were consistent with those of Gunnison and Alexander (1975). However, a linear correlation was found between $\mathrm{K}_{\mathrm{C}}$ of Microcystis spp. and water temperature ( $Y=$ $0.005 X-0.066 ; r: 0.87, \mathrm{n}: 5)$, suggesting that the decomposition rate of Microcystis spp. was greatly affected by water temperature, for it was easily decomposed in summer with high water temperature but not in winter at low water temperature.

Decomposition rate constants were different in analyzed components (Table 3 ). The relative rates of decrease of the measured parameters were as follows; chlorophyll- $a>$ particulate nitrogen $>$ particulate carbon. This suggested that detritus carbon and nitrogen were formed after the death of phytoplankton. In Lake Kasumigaura algal detritus produced by the decomposition of phytoplankton was the most important detritus for food webs (Hanazato and Yasuno, 1987). However, studies on algal detritus formation were few (MANN, 1988). It was clarified from the present study that algal detritus was rapidly produced in the initial stage of phytoplankton decomposition, and the rate of detritus decay was relatively low (Figs. 13, 14).

It was concluded from these results that about $70-90 \%$ of cell carbon and nitrogen were easily mineralized to $\mathrm{CO}_{2}$ and dissolved in organic nitrogen, and only about $10-30 \%$ changed to detritus carbon and nitrogen. At that time, about $24 \%$ (range from 0 to $50 \%$ ) of cell phosphorus was regenerated in the water in average and the remainder was in the particulate material after about one month incubation of natural phytoplankton under dark and aerating conditions.

\section{摘 要}

\section{植物プランクトンの分解による 栄養塩の回帰とデトリタス形成}

植物プランクトンの好気・暗条件下における分 解過程を霞ヶ浦の植物プランクトンを対象に調べ た。実験は 1983 年から 1985 年にかけて 8 回行っ た。光合成活性, 懸濁態窒素およびクロロフィル $a$ 濃度は $1 〜 4$ 日の遅滞時間の後に減少し始めた。 溶存態窒素抢よびリン濃度は同様な遅滞時間の後 に増加し始めた。これらのことから，暗条件下に 維持された植物プランクトンは $1 \sim 4$ 日間程度は 分解されず，その後分解が始まることが明らかに なった。

植物プランクトンの呼吸速度と分解に関与する 従属栄養微生物の酸素消費速度を区別することが 難しいところから，栄養塩類の回帰速度を酸素消 費速度から推測することは困難であることが分か つた。栄養塩の回帰速度を推定するためには直接 濃度を測定することが必要であった。

分解過程は一次反応式にしたがったが，分解速 度はクロロフィル $a>$ 䀣濁態窒素〉㲘濁態炭素の順 であった。分解速度は水温と密接な関係が認めら れたが，そのほかにも分解速度を決定する重要な 要素があることが分かった。その一つとして藻類 組成が重要であり, 藍藻類は水温が高い条件下で は容易に分解されるが理藻類は分解しにくいこと が明らかとなった。 
好気・暗条件下におかれた植物プランクトンは 約 1力月の培養で, 賏濁態炭素および窒素の 70-90 \%は無機化され炭酸ガスおよび溶存無機態窒素に なった。残りの 10-30\%の炭素および窒素がデト リタスに変化した。覞濁態りンは平均で $24 \%$ \%゙無 機化され水中に回帰してきた。残りは懸濁態の形 で残ることが分かった。

\section{Reference}

DEPinTo, J. V. and F. H. VerhofF (1977): Nutrient regeneration from aerobic decomposition of green algae. Environ. Sci. Technol., 11: 371377.

Fallon, R. D. and T. D. Brock (1979): Decomposition of blue-green algae (cyanobacterial) blooms in Lake Mendota, Wisconsin. Appl. Environ. Microbiol, 37: 820-830.

GÄCHTER, R. and A. MARES (1985): Does settling seston release soluble reactive phosphorus in the hypolimnion of lakes? Limnol. Oceanogr., 30: $364-371$.

Golterman, H. L.(1972): The role of phytoplankton in detritus formation. Mem. Ist. Ital. Idrobiol., 29 suppl: $89-103$.

Gunnison, D. and M. Alexander (1975): Resistance and susceptibility of algae to decomposition by natural microbial communities. Limnol. Oceanogr., 20: 64-70.

Hanazato, T. and M. Yasuno (1987): Evaluation of Microcystis as food for zooplankton in a eutrophic lake. Hydrobiologia, 144: 251- 259.

Healey, F. P. and L. L. Hendzel (1979): Indicators of phosphorus and nitrogen deficiency in five algae in culture. J. Fish. Res. Board Can., 36 1364-1369.

Healey, F. P. and L. L. Hendzel (1980): Physiological indicators of nutrient deficiency in lake phytoplankton. Can. J. Fish. Aquat. Sci., 37: $442-453$

MANn, K. H. (1988): Production and use of detritus in various freshwater, estuarine, and coastal marine ecosystems. Limnol. Oceanogr., 33: 910-930.

Menzel, D. W. and R. F. Vaccaro (1964): The measurement of dissolved organic and particulate carbon in sea water. Limnol. Oceanogr., 9: 138-142.

Otsuki, A. and T. HANYA (1972): Production of dissolved organic matter from dead green algal cells. I. Aerobic microbial decomposition. Limnol. Oceanogr., 17: 248-257.

Otsuki, A. and K. Sekiguchi (1983): Automated determination of ammonia in natural freshwaters using salicylate-hexacyano-ferrate-dichloroisocyanurate system. Anal. Lett., 16 (A13): 979-985.

Otsuki, A., M. Aizaki and T. KawaI (1987): Longterm variations of three types of phosphorus concentrations in highly eutrophic shallow Lake Kasumigaura, with special reference to dissolved organic phosphorus. Jpn. J. Limnol., 48: S1-S11.

Redfield, A. C., B. H. Ketchum and F. A. Richards (1963): The influence of organisms on the composition of sea water. In M. N. HoLL (ed.), The sea, 2. Interscience, N. Y.: 26-77.

STOCKLI, A. (1985): The role of bacteria and algae in phosphorus regeneration using linked continuous cultures. Verh. int. Ver. Limnol., 22: 27732779 .

Strickland, J. D. and T. PARsons (1972): A practical handbook of sea water analysis, 2nd ed, Bull. Fish. Res. Bd. Can. 167.

Takamura, N., T. Iwakuma and M. Yasuno (1987): Primary production in Lake Kasumigaura, 1981-1985. Jpn. J. Limnol., 48: S13-S38.

TezukA, Y. (1986): Does the seston of Lake Biwa release dissolved inorganic nitrogen and phos. phorus during aerobic decomposition ? Its implication for eutrophication. Ecol. Res., 1: 293-302.

TEzukA, Y. (1989a): The C: N: P ratio of phytoplankton determines the relative amounts of dissolved inorganic nitrogen and phosphorus released during aerobic decomposition. Hydrobiologia, 173: 55-62.

Tezuka, Y. (1989b): The C: N: P ratio of Microcystis and Anabena (blue-green algae) and its importance for nutrient regeneration by aerobic decomposition. Jpn. J. Limnol., 50: 149- 155.

Watanabe, Y. and F. Kimura (1990): Effect of cellular carbohydrate content and nutrient status on the respiratory oxygen uptake rate of a Microcystis population in a eutrophic pond. Mari. Micro. Food Webs, 4: 129-138.

(著者：相崎守弘, 国立環境研究所地域環境研究グル ープ: 高村典子, 国立環境研究所生物圈罟境部, 7305 茨城県つくば市小野川 16-2；Morihiro AIZAKI, Noriko TAKamURA, the National Institute for Environmental Studies, Onogawa, Tsukuba, Ibaraki 305.

Received: 9 June 1990

Accepted: 12 January 1991 